\title{
New Method for Nucleophilic Substitution on Hexachlorocyclotriphosphazene by Allylamine Using an Algerian Proton Exchanged Montmorillonite Clay (Maghnite-H+) as a Green Solid Catalyst
}

\author{
Lahouaria Medjdoub*, Belbachir Mohammed \\ Laboratory of Polymer Chemistry, Department of Chemistry, Faculty of Exact and Applied \\ Sciences, University of Oran1 Ahmed BenBella, BP 1524 El M'Naouar, 31000 Oran, Algeria
}

Received: 28th September 2015; Revised: $5^{\text {th }}$ December 2015; Accepted: $4^{\text {th }}$ January 2016

\section{Abstract}

Nucleophilic substitution on hexachlorocyclotriphosphazene (HCCTP) with allylamine in order to give hexa(allylamino)cyclotriphosphazene (HACTP) is performed for the first time under mild conditions by using diethylether as solvent to replace benzene due to its toxicity. The reaction time is reduced to half and also performed at room temperature but especially in the presence of an eco-catalyst called Maghnite- $\mathrm{H}^{+}$. This catalyst has a significant role in the industrial scale. In fact, the use of Maghnite is preferred for its many advantages: a very low purchase price compared to other catalysts, the easy removal of the reaction mixture. Then, Maghnite- $\mathrm{H}^{+}$is became an excellent catalyst for many chemical reactions. The structure of HACTP synthesized in the presence of Maghnite- $\mathrm{H}^{+}$to $5 \%$ by weight is confirmed by ${ }^{1} \mathrm{H}-\mathrm{NMR},{ }^{13} \mathrm{C}-\mathrm{NMR},{ }^{31} \mathrm{P}-\mathrm{NMR}$ (Nuclear magnetic resonance) and FTIR (Fourier Transform Infrared spectroscopy). MALDI-TOF (Matrix-Assisted Laser Desorption/Ionisation-time-of-flight mass spectrometry) is used to establish the molecular weight of HACTP which is $471 \mathrm{~g} / \mathrm{mol}$. DSC (Differential Scanning Calorimetry) and TGA (Thermogravimetric Analysis) show that HACTP is a crystalline product with a melting point of $88^{\circ} \mathrm{C}$. It is reactive after melting but is degraded from 230 ${ }^{\circ} \mathrm{C}$. Copyright $(\mathrm{C} 2016$ BCREC GROUP. All rights reserved

Keywords: Hexachlorocyclotriphosphazene; Allylamine; Nucleophilic substitution; Maghnite-H+; NMR spectroscopy; Thermal properties

How to Cite: Medjdoub, L., Mohammed, B. (2016). New Method for Nucleophilic Substitution on Hexachlorocyclotriphosphazene by Allylamine Using an Algerian Proton Exchanged Montmorillonite Clay (Maghnite-H+) as a Green Solid Catalyst. Bulletin of Chemical Reaction Engineering \& Catalysis, 11 (2): 151-160 (doi:10.9767/bcrec.11.2.541.151-160)

Permalink/DOI: http://dx.doi.org/10.9767/bcrec.11.2.541.151-160

\section{Introduction}

Phosphazenes are inorganic compounds which belong to the most important class of cy-

* Corresponding Author.

E-mail: houariamejdoub@yahoo.fr (L. Medjdoub),

Telp: (+213)778256833 clic or linear structure of general formula $\left(\mathrm{R}_{2} \mathrm{P}=\mathrm{N}\right)_{n}$. The degree of polymerization " $\mathrm{n}$ " may vary from 3 to more thousand. $\mathrm{R}$ can be a halogen, alkyl, aryl, amine, alkoxy, and other groups. Cyclophosphazenes are cyclic trimers $\left(\mathrm{R}_{2} \mathrm{P}=\mathrm{N}\right)_{3}$ and when $\mathrm{R}$ represents halogen $\mathrm{Cl}$, there will be formation of hexachlorocyclotriphosphazene $\quad(\mathrm{HCCTP}) \quad\left(\mathrm{N}=\mathrm{Cl}_{2} \mathrm{P}\right)_{3}$ 
(Figure 1). HCCTP is prepared from ammonium chloride and pentachloride phosphorus. It is an inorganic compound which has a basic character [1, 2]. The physical properties of HCCTP are summarized in Table 1.

Nucleophilic substitution on HCCTP is the main way to the synthesis of hybrid compounds (organic-inorganic) called organophosphazenes [3-5]. The choice of the monomer organophosphazene is justified by the importance of its use in the production of toric joint, gas pipes and a variety of joints, for storing and transferring oils and fuels. Some derivatives compounds are microcrystalline (influence of $\mathrm{R}$ ) and can be used in the production of flexible films and fibers $[6,7]$. Many derivatives are biocompatible, biodegradable and some of them are bioactive and are studied for their potential medical applications [8-10]. There are also polymers synthesized from organophosphazenes monomers [11-13] which have exceptional elastomers properties [14] and are used as solid electrolytes in the production of rechargeable batteries of low weight [15-17].

These organophosphazenes have a great importance by their many applications, so a particular interest is given to nucleophilic substitution on hexachlorocyclophosphazene (HCCTP) by allylamine according to the method of Christova et al. [18] to give hexa(allylamino)cyclotriphosphazene (HACTP) but operating under milder process conditions. In fact, the originality of this work consists in the synthesis of HACTP using a clay called "Maghnite-H+" as a catalyst [19]. It is very ecological, economic and regenerable by simple filtration. The synthesis method of Christova et al. [18] is also modified by replacing benzene, which is carcinogenic, by diethylether as solvent.

\section{Materials and Methods}

\subsection{Materials}

Maghnite used in this work comes from a quarry located in Maghnia (North West of Algeria) and was supplied by company "ENOF" (Algerian manufacture specialized in the pro- duction of nonferric products and useful substances). Hexacholocyclotriphosphazene (HCCTP) (Sigma Aldrich, 99\%) (Figure 1 and Table 1), allylamine (Fluka, 98\%), benzene (Fluka, 99\%) and diethylether (Sigma Aldrich, 99,5\%) were purchased without further purification.

\subsection{Preparation of Maghnite-H+}

The preparation of Maghnite-H+ was carried out by using a method similar to that described by Belbachir and coworkers [20]. In an Erlenmeyer flask of $500 \mathrm{~mL}, 30 \mathrm{~g}$ of crushed and dried raw-maghnite were dispersed in 120 $\mathrm{mL}$ of distilled water, the mixture was stirred for 2 hours. After this time, $100 \mathrm{~mL}$ of $2.5 \mathrm{M}$ sulfuric acid solution was added, the solution thus obtained was kept under stirring for two days at room temperature. Then, the product was filtered and washed with distilled water until complete disappearance of traces of acid. Once purified clay, it was dried overnight in an oven at $105{ }^{\circ} \mathrm{C}$, and then stored in vials well saddled against moisture and any impurity.

\subsection{Synthesis of hexa(allylamino) cyclotriphosphazene}

Nucleophilic substitution on HCCTP $\left(\mathrm{N}_{3} \mathrm{P}_{3} \mathrm{Cl}_{6}\right)$ by allylamine $\left(\mathrm{NH}_{2}-\mathrm{CH}_{2}-\mathrm{CH}=\mathrm{CH}_{2}\right)$ is performed as is described by Christova et al. [18]. To a stirred solution of $3 \mathrm{~mL}(0.040 \mathrm{~mol})$ of allylamine in $3.33 \mathrm{~mL}$ of benzene, $1 \mathrm{~g}(0.0028$ mol) of HCCTP dissolved in $5 \mathrm{~mL}$ of benzene was added dropwisely. The reaction mixture was stirred for 24 hours at room temperature. The volatile solvents were removed in a rotary evaporator and the remaining solid was ex-

Figure 1. Structure formula of HCCTP

Table 1. Physical Properties of HCCTP<smiles>ClP1(Cl)=NP(Cl)(Cl)=NP(Cl)(Cl)=N1</smiles>

\begin{tabular}{cccccc}
\hline Appearance & $\mathrm{Fw}(\mathrm{g} / \mathrm{mol})$ & $\begin{array}{c}\mathrm{Mp} \\
{ }^{\circ} \mathrm{C}(\mathrm{lit} .)\end{array}$ & $\begin{array}{c}\mathrm{Bp} \\
{ }^{\circ} \mathrm{C}(13 \mathrm{mmHg})\end{array}$ & $\begin{array}{c}\mathrm{D} \\
(\mathrm{g} / \mathrm{mL}) \\
\text { at } 25{ }^{\circ} \mathrm{C}(\mathrm{lit} .)\end{array}$ & $\mathrm{CAS}$ \\
\hline $\begin{array}{c}\text { White crystalline } \\
\text { powder }\end{array}$ & 347.66 & $112-115$ & 127 & 1.98 & {$[940-71-6]$} \\
\hline
\end{tabular}


tracted with several portions of diethylether. The crystallized product thus obtained was recrystallized from cyclohexane and the yield was $64 \%$.

\subsection{Synthesis of hexa(allylamino) cyclotriphosphazene using Maghnite-H+}

The synthesis of HACTP was conducted from HCCTP and allylamine as starting materials with the addition of a catalyst which was Maghnite- $\mathrm{H}+$ at $5 \%$ by weight and using diethylether as solvent to replace benzene. The reaction time was reduced to $12 \mathrm{~h}$. At the end of the reaction, chloroform was added to the solution and then filtered to separate the product from Maghnite-H+. Then, the final product was purified by recrystallization. The yield was $74 \%$. Operating conditions of the synthesis of HACTP, according to the method of CHRISTOVA and in the presence of Maghnite-H+, were summarized in Table 2.

\subsection{Characterization of products}

${ }^{1} \mathrm{H}-\mathrm{NMR},{ }^{13} \mathrm{C}-\mathrm{NMR}$ and ${ }^{31} \mathrm{P}-\mathrm{NMR}$ spectra were recorded in $\mathrm{CDCl}_{3}$ solution under room temperature on an AM 300 FT Bruker spectrometer using tetramethylsilane as internal standard. FTIR absorption spectra were recorded on an MATTSON GENESIS II FT-IR spectrometer using the $\mathrm{KBr}$ pressed disc technique. Thermogravimetric analyzes were recorded on a SETARAM Labsys TG-DTA/DSC (room temperature $-1600{ }^{\circ} \mathrm{C}$ ) with a nitrogen sweep of $200 \mathrm{~mL} / \mathrm{min}$ at a heating rate of 10 ${ }^{\circ} \mathrm{C} /$ min. DSC measurements were carried out on a TA instrument (TGA Q500), according to the following program: products were first heated from ambient temperature to $250{ }^{\circ} \mathrm{C}$ at $10^{\circ} \mathrm{C} / \mathrm{min}$ maintained at this temperature during 5 min then cooled to $25{ }^{\circ} \mathrm{C}$ at $20^{\circ} \mathrm{C} / \mathrm{min}$. The MALDI-TOF spectra have been carried out in a Bruker microflex, the samples were prepared in $\mathrm{CHCl}_{3}$ with Dithranol as matrix.

\section{Results and Discussion}

\subsection{Characterization of the catalyst (Maghnite-H+)}

Table 3 shows the variation of the elementary chemical composition of the Raw-Maghnite before and after its activation with $2.5 \mathrm{M}$ sulfuric acid solution. It is observed that the acid treatment leads to a decrease in $\mathrm{Al}_{2} \mathrm{O}_{3}$ and an increased percentage of $\mathrm{SiO}_{2}$ in the material.

The X-ray powder diffraction profiles (Figure 2) exhibit the increase in basal spacing from $12.5 \AA$ in the Raw-Maghnite, characteristic of a single water layer between the sheets, to a $15.02 \AA$ value in Maghnite- $\mathrm{H}^{+}$for two interlamellar water layers reflecting the changes in interlayer cation and its associated hydration state as a result of the acid treatment.

The FTIR spectra of the treated Maghnite (Figure 3) confirmed the montmorillonite structure of the Maghnite- $\mathrm{H}^{+}$. The characteristic absorption of the $\mathrm{OH}$ groups linked to the octahedral aluminum is observed by a broad band between $3200 \mathrm{~cm}^{-1}$ and $3400 \mathrm{~cm}^{-1}$. The strong band at $1007 \mathrm{~cm}^{-1}$ corresponds to the $\mathrm{Si}-\mathrm{O}$ stretching vibration in the tetrahedral layer. Angular deformation bands at 518 and $449 \mathrm{~cm}^{-1}$ are assigned to the type links of Si-OM smectites, $\mathrm{M}$ may be $\mathrm{Mg}, \mathrm{Al}$ or $\mathrm{Fe}$.

Table 2. Synthesis of HACTP in diethylether catalyzed by Maghnite-H+

\begin{tabular}{cccccc}
\hline Product & Catalyst & Solvent & Time (h) & Temperature $\left({ }^{\circ} \mathrm{C}\right)$ & $\begin{array}{c}\text { Yield } \\
(\%)\end{array}$ \\
\hline HACTP $^{(1)}$ & ---- & Benzene & 24 & 20 & 64 \\
HACTP $^{(2)}$ & Maghnite-H+ $(5 \% \mathrm{w})$ & Diethylether & 12 & 20 & 74 \\
\hline
\end{tabular}

(1) HACTP synthesized according to the method of Christova [18].

(2) HACTP synthesized in the presence of Maghnite-H+ as catalyst

Table 3. Chemical composition of Protons exchanged sample "Maghnite-H+" (composition wt\%).

\begin{tabular}{lccccccccc}
\hline \multicolumn{1}{c}{ Sample } & $\mathrm{SiO}_{2}$ & $\mathrm{Al}_{2} \mathrm{O}_{3}$ & $\mathrm{Fe}_{2} \mathrm{O}_{3}$ & $\mathrm{CaO}$ & $\mathrm{MgO}$ & $\mathrm{Na}_{2} \mathrm{O}$ & $\mathrm{K}_{2} \mathrm{O}$ & $\mathrm{TiO}_{2}$ & $\mathrm{SO}_{3}$ \\
\hline $\begin{array}{l}\text { Raw- } \\
\text { Maghnite }\end{array}$ & 69.3 & 14.67 & 1.16 & 0.30 & 1.07 & 0.50 & 0.79 & 0.16 & 0.91 \\
Maghnie- $\mathrm{H}^{+}$ & 71.7 & 14.03 & 0.71 & 0.28 & 0.80 & 0.21 & 0.77 & 0.15 & 0.34 \\
\hline
\end{tabular}




\subsection{Characterization of HATCP catalysed by Maghnite- $\mathbf{H}^{+}$}

Figure 4 shows that the most characteristic bond in the FTIR spectrum of HCCTP is the band of $\mathrm{N}=\mathrm{P}$ group degenerated in the area of $1200 \mathrm{~cm}^{-1}$. This frequency is not only influenced by single and double bond, but also by the electronegativity of the groups linked to phosphorus. The characteristic peaks appeared at 505 and $594 \mathrm{~cm}^{-1}$ are assigned to two P-Cl bonds. When the Chloro groups of HCCTP are substituted with allylamine, the resulting HACTP has

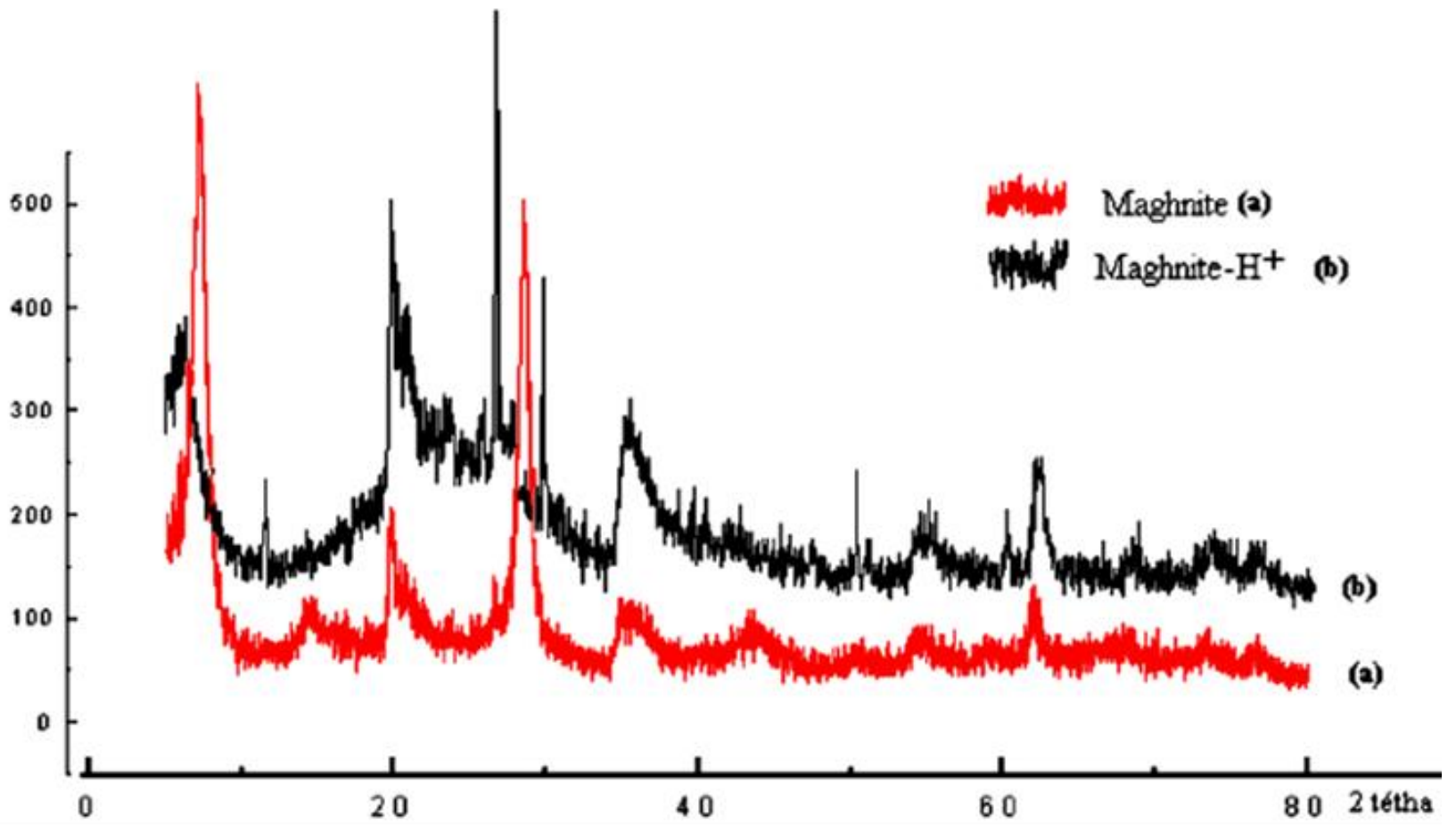

Figure 2. X-ray powder diffraction of (a) "Raw-Maghnite" and (b) "Maghnite-H+"

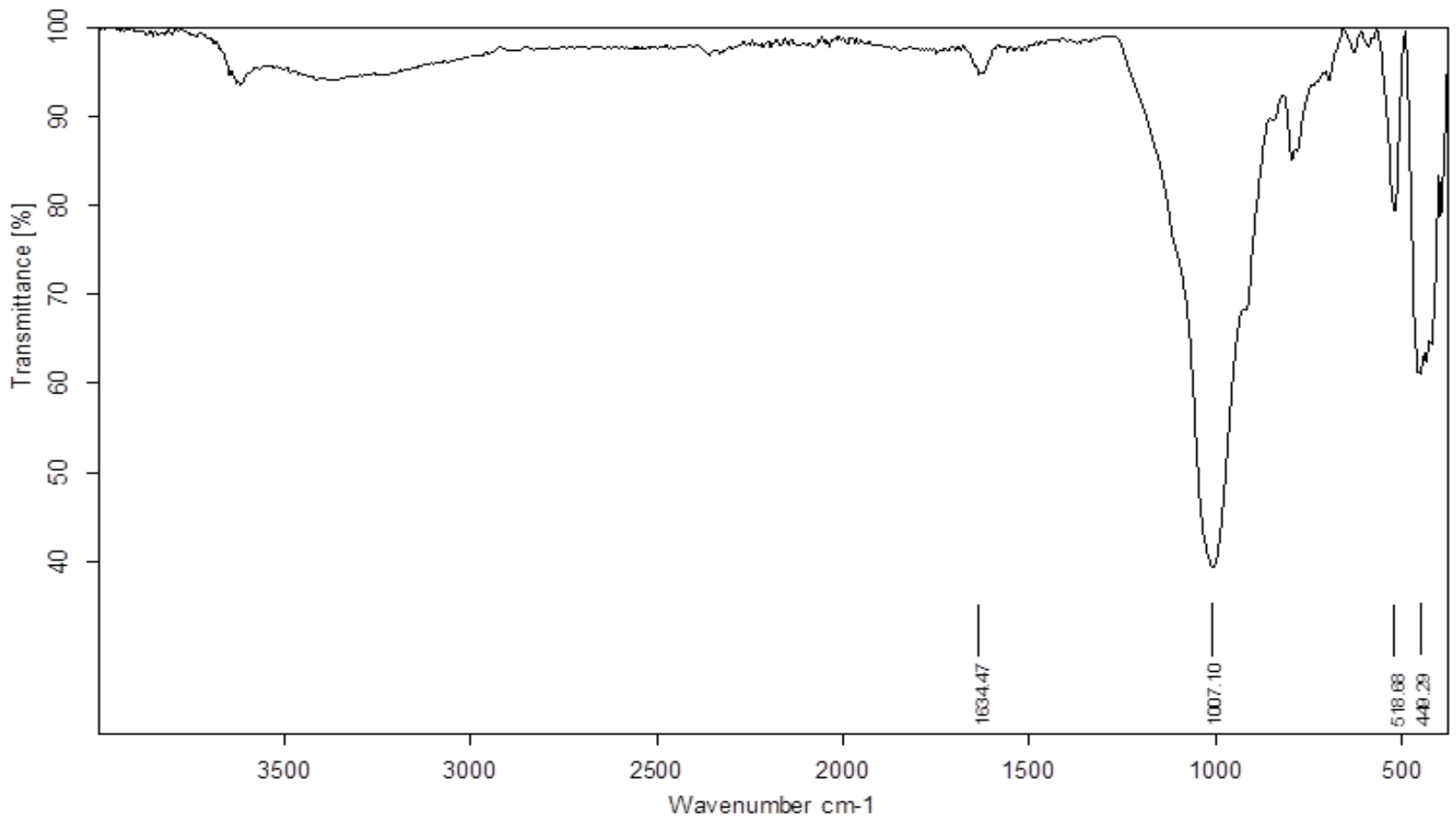

Figure 3. FTIR spectrum of Maghnite-H+ 
FTIR spectrum shown in Figure 5. The spectrum shows characteristic peaks at $3450 \mathrm{~cm}^{-1}$ corresponding to N-H groups, and at 1644 and $967 \mathrm{~cm}^{-1}$ for $\mathrm{C}=\mathrm{C}$ bonds. The absorption band at $1204 \mathrm{~cm}^{-1}$ assigned to $\mathrm{N}=\mathrm{P}$ group in the starting material becomes $1254 \mathrm{~cm}^{-1}$ in HACTP, confirming that $\mathrm{Cl}$ atom attached to phosphorus has been substituted by another electrondonating group, which explains the increase in the value of the absorption band assigned to the group $\mathrm{P}=\mathrm{N}$.

The chemical structure of HATCP is further supporter by ${ }^{1} \mathrm{H}-\mathrm{NMR},{ }^{13} \mathrm{C}-\mathrm{NMR}$ and ${ }^{31} \mathrm{P}-\mathrm{NMR}$ spectra. The different signals observed in the ${ }^{1} \mathrm{H}-\mathrm{NMR}$ spectrum of Figure 6 and which are summarized in Table 4, correspond to the groups shown in the structural formula of HACTP catalyzed by Maghnite- $\mathrm{H}^{+}$at $5 \%$ wt. The resonance peak at $2.276 \mathrm{ppm}$ is assigned to proton linked to Nitrogen $\left(\mathrm{N}-\mathrm{H}_{\mathrm{A}}\right)$. This peak confirm that nucleophilic substitution on HCCTP has been occurred. The ${ }^{13} \mathrm{C}$-NMR spectrum clearly shows three resonance peaks with their carbons assigned in Figure 7 . In the ${ }^{31} \mathrm{P}$ -

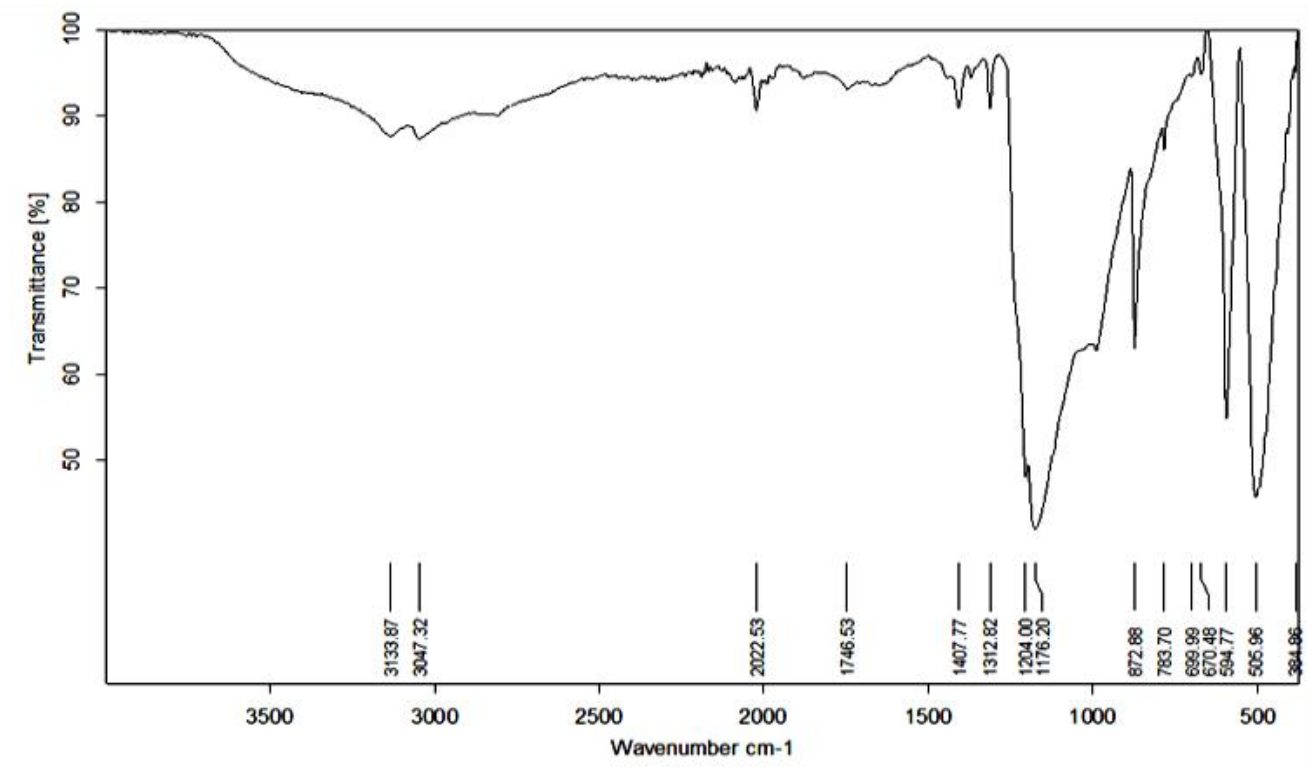

Figure 4. FTIR spectrum of HCCTP

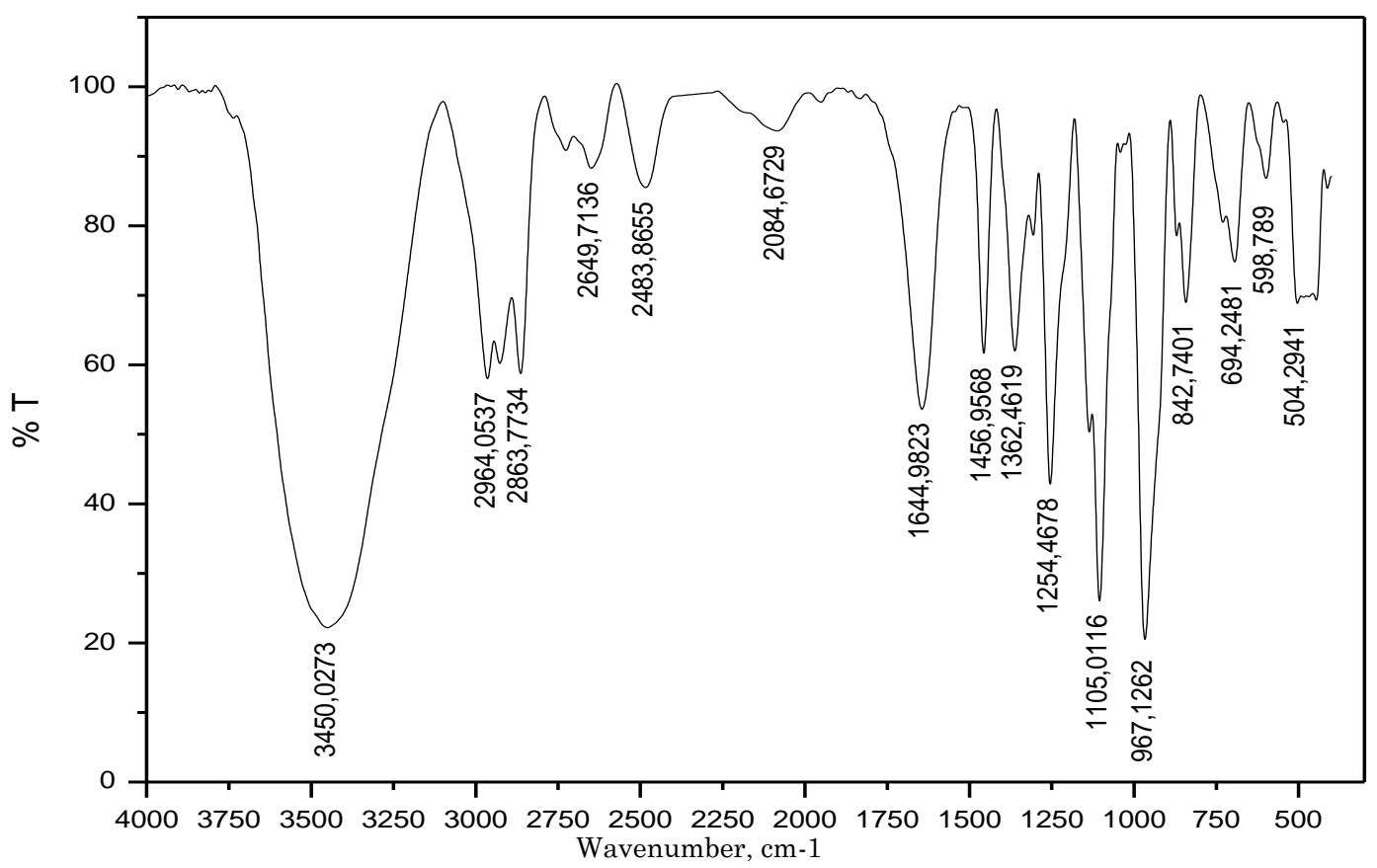

Figure 5. FTIR spectrum of HACTP catalyzed by Maghnite-H+ (5 \%wt) 


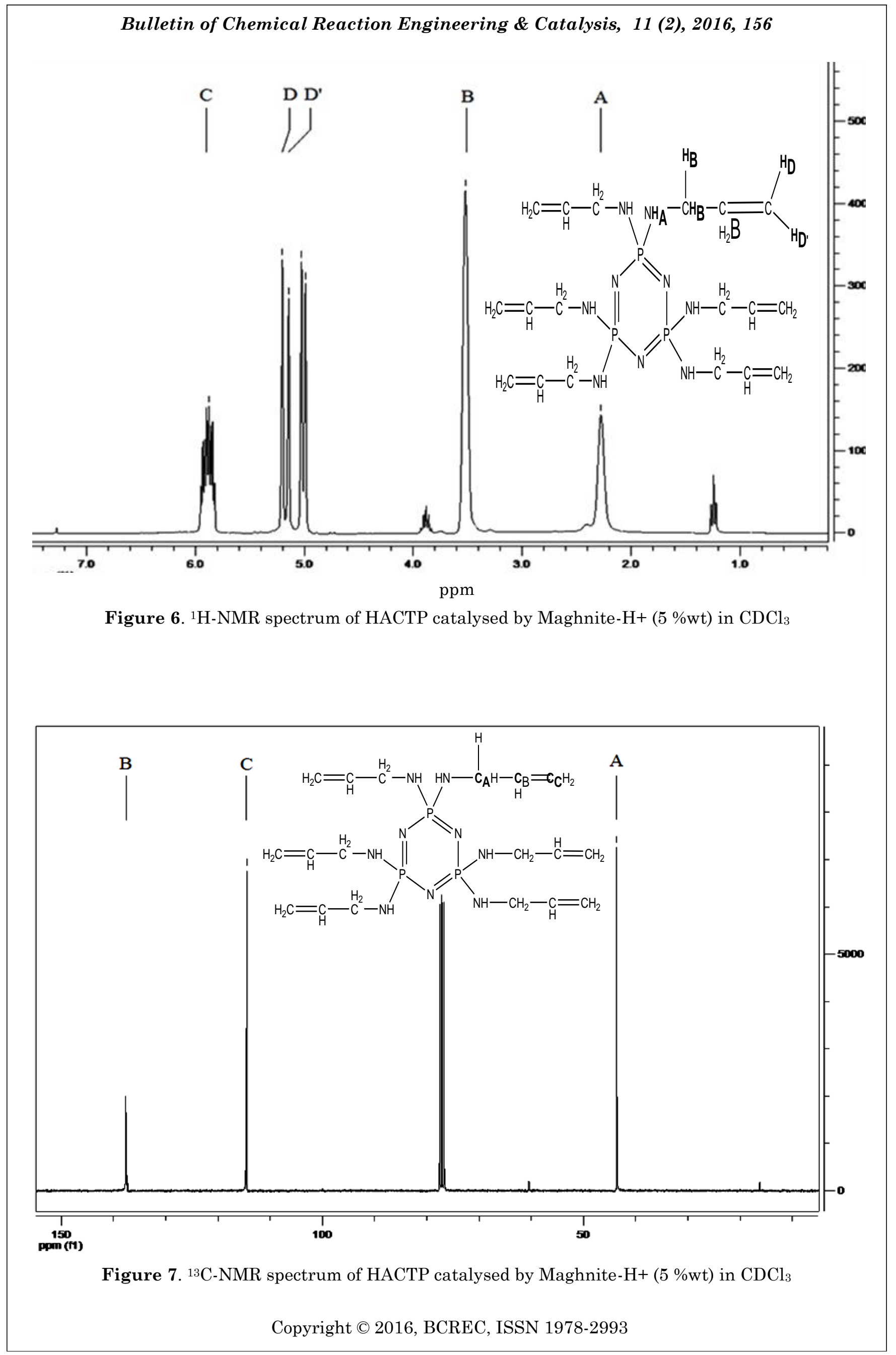




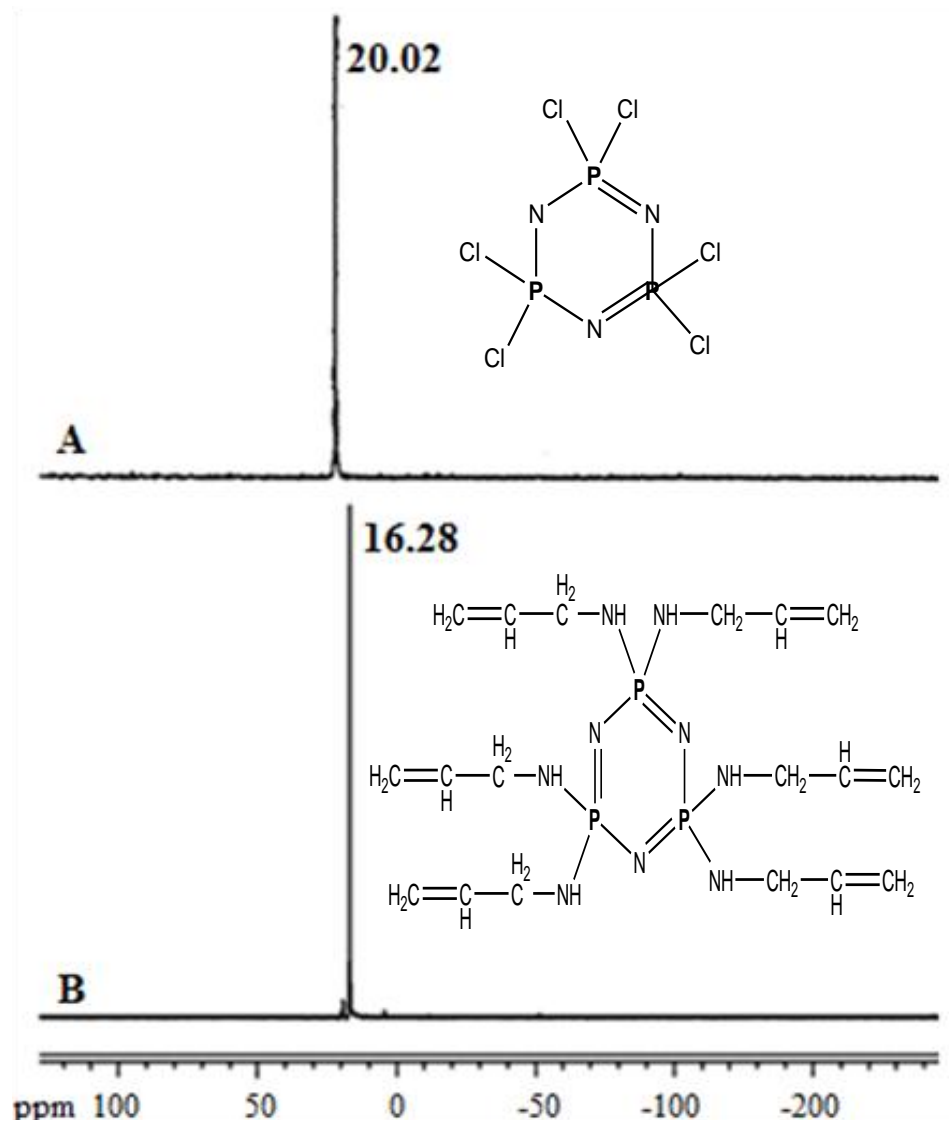

Figure 8. ${ }^{31} \mathrm{P}-\mathrm{NMR}$ spectrum of A) HCCTP [21], B) HACTP catalysed by Maghnite-H+ (5 \%wt) in $\mathrm{CDCl}_{3}$

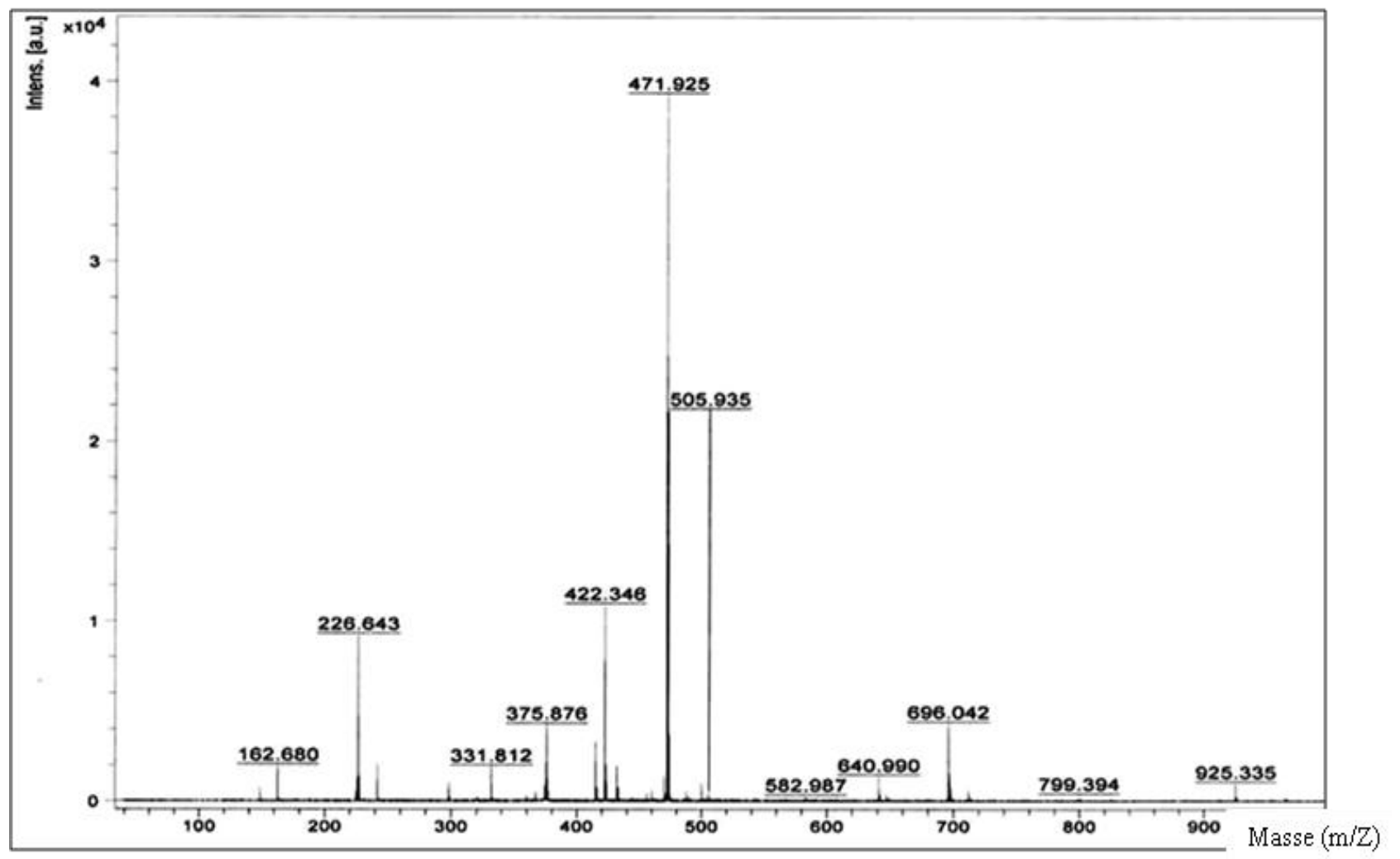

Figure 9. Mass spectrum of HACTP catalyzed by Maghnite-H+ (5\%wt) 


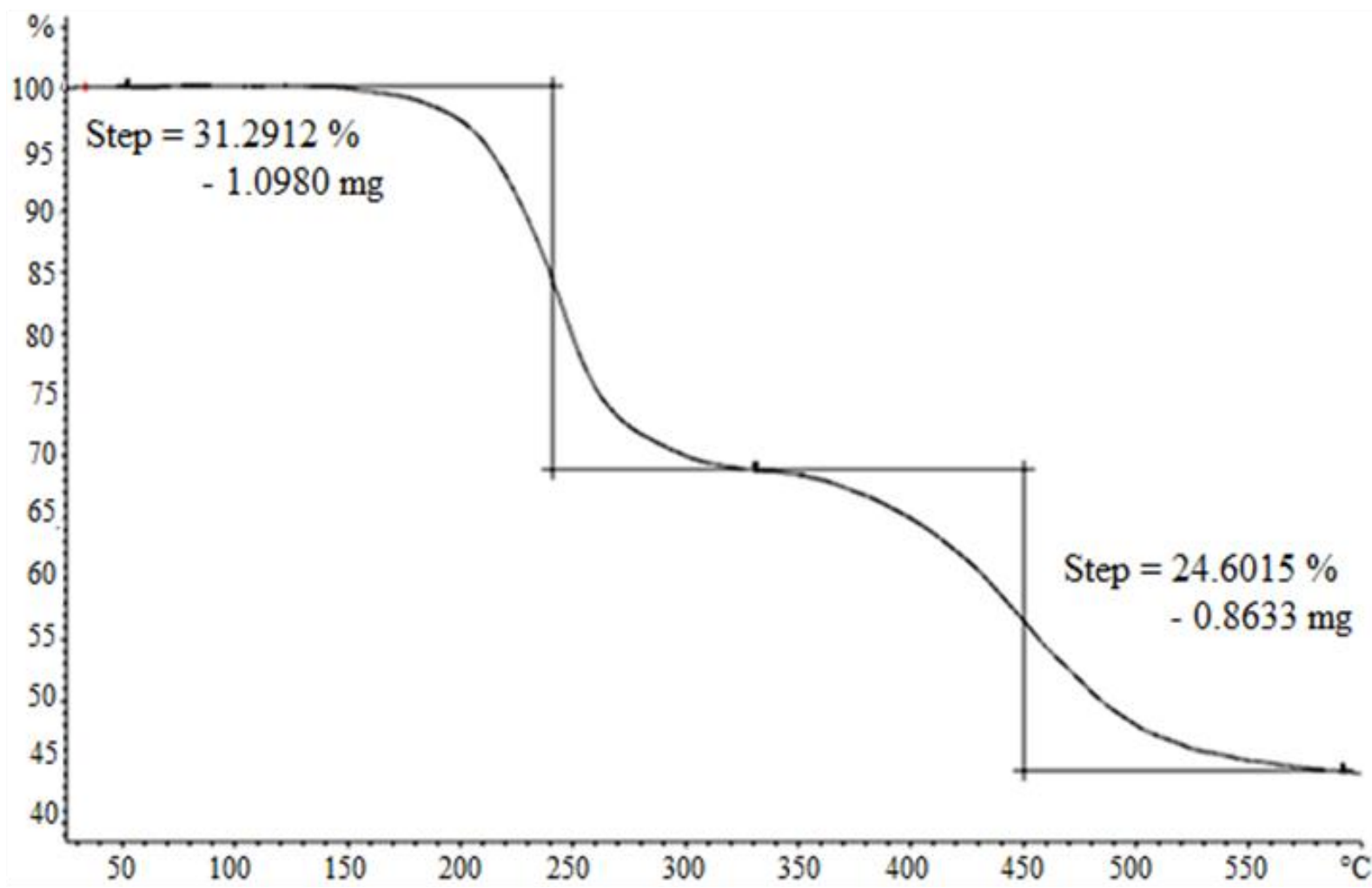

Figure 10. TGA thermogram of HACTP catalyzed by Maghnite-H+ (5\%wt) obtained in Nitrogen atmosphere at heating rate of $10^{\circ} \mathrm{C} / \mathrm{min}$

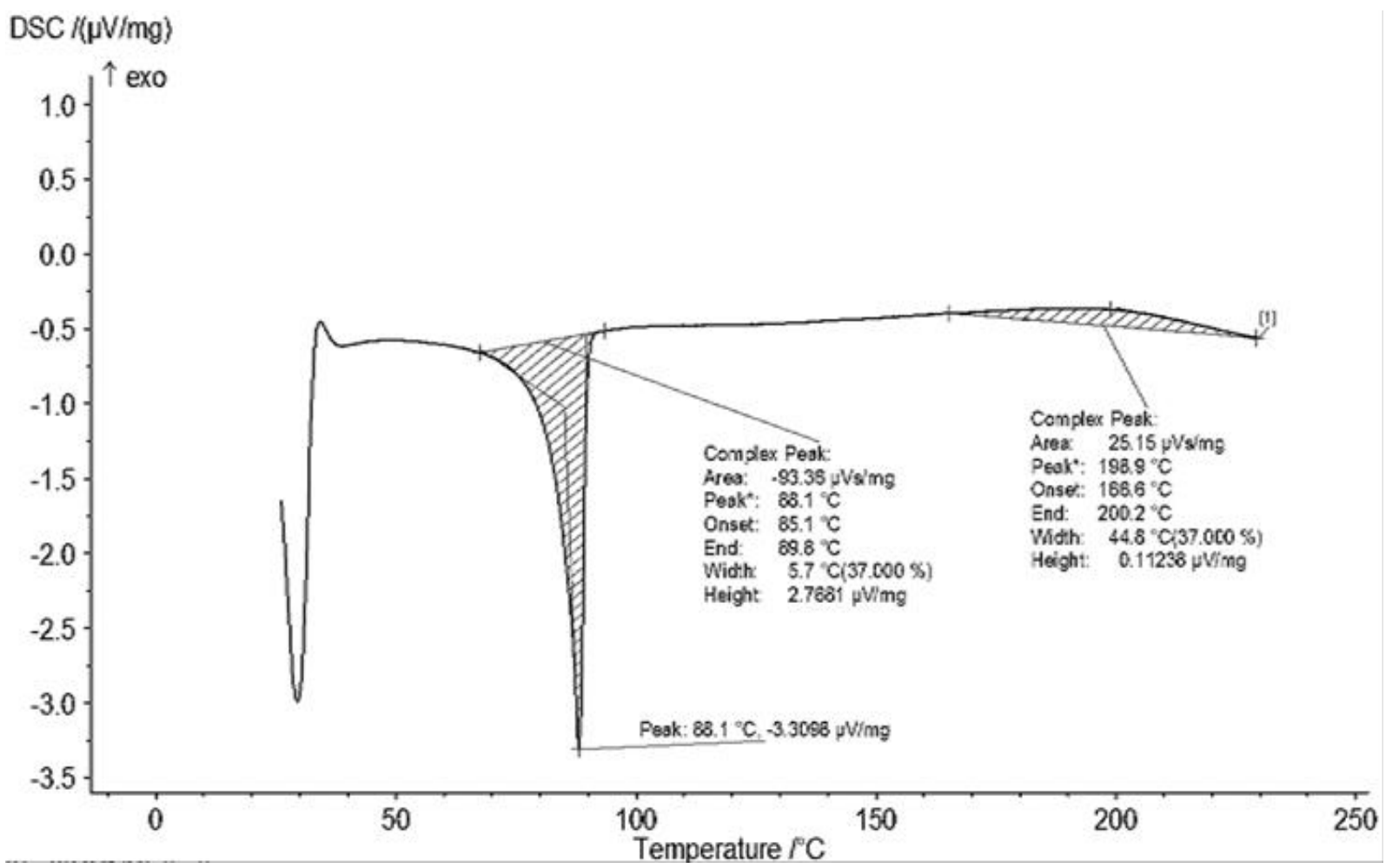

Figure 11. DSC thermogram of HACTP catalyzed by Maghnite-H+ (5\%wt) obtained in Nitrogen atmosphere at heating rate of $10^{\circ} \mathrm{C} / \mathrm{min}$ 
NMR spectrum of HACTP (Figure 8-A), there is one peak appeared at $16 \mathrm{ppm}$. For comparison, the ${ }^{31} \mathrm{P}-\mathrm{NMR}$ of HCCTP [21], also in Figure 8$\mathrm{B}$, has resonance peak located at $20 \mathrm{ppm}$. The molecular weight of HACTP determined from the mass spectrometry is 471 (Figure 9). Other significant observation on the mass spectrum of HACTP is its fragmentation to $\mathrm{m} / \mathrm{e} 422,375$, 331 , and 226.

The TGA data of HACTP shown in Figure 10 indicates a two-stage degradation behavior. The first stage of degradation at around 230$320{ }^{\circ} \mathrm{C}$. It is proceeded by the cleavage of two allylamine groups remaining $31.29 \mathrm{wt} \%$ residue, and then proceeded with the cleavage of another two allylamine groups after $400{ }^{\circ} \mathrm{C}$. The DSC result shown in Figure 11 indicates that HACTP is a highly crystalline material with a melting temperature of $88.1^{\circ} \mathrm{C}$. It is mildly reactive after melt with the maximum reaction temperature at $198.9^{\circ} \mathrm{C}$.

\section{Conclusions}

In this work, a new synthetic method was developed to produce HACTP using friendly, green, ecologic and non toxic catalyst clay as proton source avoiding the use of benzene as a solvent because it is carcinogenic, so it is replaced by diethyl ether which is less toxic. The synthesis of HACTP is also carried out at room temperature with a halving of reaction time from 24 to $12 \mathrm{~h}$ which is very attractive from an industrial point of view. The simplicity of the synthesis method, good catalytic properties of the support catalyst Maghnite $-\mathrm{H}^{+}$and the use of non toxic solvent make this an attractive way for the synthesis of hexa(allylamino)cyclotriphosphazene.

Table 4. Different signals of Protons of HACTP catalyzed by Maghnite-H+ (5\%wt).

\begin{tabular}{cc}
\hline Resonance peaks $(\mathrm{ppm})$ & Attribution \\
\hline 2.276 & $\mathrm{HA}$ \\
3.520 & $\mathrm{HB}$ \\
5.896 & $\mathrm{HC}$ \\
$5.145,5.202$ & $\mathrm{HD}$ \\
7.2 & $\mathrm{CDCl}_{3}$ \\
\hline
\end{tabular}

\section{Acknowledgments}

The authors would like to especially thank A. Addou (Laboratory of Polymer Chemistry, University of Oran, Algeria) for the ATG, DSC and FT-IR analysis of polymers. We also appreciate the help of M. AKEB (Laboratory of Polymer Chemistry, University of Oran, Algeria) for recording the NMR analysis.

\section{References}

[1] Isıklan, M., Asmafiliz N., Özalp, E.E., Ilter, E.E., Kılıç, Z., Çosut, B., Yesilot, S., Kılıç, A., Öztürk, A., Hökelek, T., Koç, L.Y., Akyüz, L.E. (2010). Phosphorus-nitrogen compounds. 21. Syntheses, structural investigations, biological activities, and DNA interactions of new N/O spirocyclic phosphazene derivatives. The NMR behaviors of chiral phosphazenes with stereogenic centers upon the addition of chiral solvating agents. Inorganic Chemistry, 49: 7057-7071.

[2] Asmafiliz, N., Kılıç, Z., Öztürk, A., Hökelek, T., Koç, L.Y., Açık, L., Kısa, Ö., Albay, A., Üstündag, Z., Solak, A.O. (2009). Phosphorus-nitrogen compounds. 18. Syntheses, stereogenic properties, structural and electrochemical investigations, biological activities, and DNA interactions of new spirocyclic mono- and bisferrocenylphosphazene derivatives. Inorganic Chemistry, 48: 1010210116.

[3] Elmas, G., Okumuş, A., Kılıç, Z., Hökelek, T., Açık, L., Dal, H., Ramazanoğlu, N., Koç, L.Y. (2012). Phosphorus-nitrogen compounds. Part 24. Syntheses, crystal structures, spectroscopic and stereogenic properties, biological activities, and DNA interactions of novel spiro-ansa-spiro- and ansaspiro-ansa-cyclotetraphosphazenes. Inorganic Chemistry, 51: 12841-12856.

[4] Chandrasekhar, V., Thilagar, P., Pandian, B.M. (2007). Cyclophosphazene-based multisite coordination ligands. Coordination Chemistry Reviews, 251: 1045-1074

[5] Uslu, A., Coles, S.J., Davies, D.B., Esen, M., Hursthouse, M.B., Kılıç, A. (2010). Effect of gem 2,2' -disubstitution and base in the formation of spiro- and ansa-1,3-propandioxy derivatives of cyclotriphosphazenes. Inorganica Chimica Acta, 363: 3506-3515

[6] Li, Z., Qin, J. (1979). Synthesis of C60containing polyphosphazenes from a new reactive macromolecular intermediate: Polyphophazene azides. Journal of Polymer Science, Part A: Polymer Chemistry, 42:194-199

[7] Li, Z., Qin, J., Xu, X. (2004). New approaches for the synthesis of hindered C60containing polyphosphazenes via functiona- 
lized intermediates. Journal of Polymer Science, Part A: Polymer Chemistry, 42: 2877 2885.

[8] Singh, A., Krogman, N.R., Sethurman, S., Nair, L.S., Sturgeon, J.L., Brown, P.W., Laurencin, C.T., Allcock, H.R. (2006). Effect of side group chemistry on the properties of biodegradable L-alanine cosubstituted polyphosphazenes. Biomacromolecules, 7: 914-918.

[9] Greish, Y.E., Bender, J.D., Lakshmi, S., Brown, P.W., Allcock, H.R., Laurencin, C.T. (2005). Low temperature formation of hydroxyapatite-poly(alkyl oxybenzoate)phosphazene composites for biomedical applications. Biomaterials, 26: 1-9.

[10] Brunton, S. A., Stibbard, J. H. A., Rubin, L. L., Kruse, L. I., Guicherit, O. M., Boyd, E. A., Price, S. (2008). Potent Inhibitors of the Hedgehog Signaling Pathway. Journal of Medicinal Chemistry, 51: 1108-1110.

[11] Çosut, B., Hacıvelioglu, F., Durmus, M., Kılıç, A., Yesilot, S. (2009). The synthesis, thermal and photophysical properties of phenoxycyclotriphosphazenyl-substituted cyclic and polymeric phosphazenes. Polyhedron, 28: $2510-2516$.

[12] Allcock, H.R. (2006). Recent developments in polyphosphazene materials science. Current Opinion in Solid State Materials Science, 10: 231-240.

[13] Gleria, M., Jaeger, R.D. (2004). Phosphazenes a worldwide insight. Nova Science Publishers Incorporation, Hauppauge, New York.

[14] Allcock, H.R., Napierala, M.E., Cameron, C.G., O'Connor, S.J.M. (1996). Synthesis and Characterization of Ionically Conducting Alkoxy Ether/Alkoxy Mixed-Substituent Poly(organophosphazenes) and Their Use as Solid Solvents for Ionic Conduction. Macromolecules, 29: 1951-1956.
[15] Xu, G., Lu, Q., Yu, B., Wen, L. (2006). Inorganic polymer phosphazene disulfide as cathode material for rechargeable lithium batteries. Solid State Ionics, 177: 305-309.

[16] Allcock, H.R., Wood, R.M. (2006). Design and synthesis of ion-conductive polyphosphazenes for fuel cell applications: Review. Journal of Polymer Science, Part B. Polymer Physics, 44: 2358-2368.

[17] Li, Z., Qin, J., Li, S., Ye, C., Luo, J., Cao, Y. (2002). Polyphophazene Containing IndoleBased Dual Chromophores: Synthesis and Nonlinear Optical Characterization. Macromolecules, 35: 9232-9235.

[18] Christova, D., Ivanova, S. D., Velichkova, R. S., Tzvetkova, P., Mihailova, P., Uzunov, I., Lakov, L., Peshev, O. (2003). Organicinorganic composites based on cyclotriphosphazene-cross-linked PHEMA networks. Designed Monomers and Polymers, 6: 11-21.

[19] Belbachir, M. (2001). US Patent. 066969.0101.

[20] Belbachir, M., Bensaoula, A. (2001). Composition and method for catalysis using bentonites. US Patent. US6274527.

[21] Kuan, J. F., Lin, K. F. (2004). Synthesis of Hexa(allylamino)cyclotriphosphazene as a reactive fire retardant for unsaturated polyesters. Journal of Applied Polymer Science, 91: 697-702. 